\title{
EDITORIAL
}

\section{Music education in context: A special feature for the London Review of Education}

Hilary McQueen* and Maria Varvarigou

UCL Institute of Education, University College London

The power of music to enrich and enhance people's lives is well documented. There are numerous examples of the positive impact of music education. The contexts in which people of all ages learn about music vary widely, yet each can provide the catalyst for engagement with music that can have both individual and more extensive benefits. Therefore, particularly at a time of financial constraints and global unrest, it is important that the contribution of education in the arts, such as music, is kept to the fore.

The aim of this special feature was to draw on research and practice that illustrated the effect of music education in specific contexts. The result is a range of articles that demonstrate the extent to which music can provide a catalyst for individual, group and wider social benefits. The articles also provide an opportunity to think about teaching and learning more generally.

The potential for music to enhance learning in other curriculum areas has been widely reported. Susan Hallam provides a convincing account of the contribution that music can make to developing aural perception and language skills in a variety of music education contexts with reference to a wealth of research. This is complemented by an article co-authored by Sylwia Holmes and Susan Hallam demonstrating the potential that music has for the development of mathematical skills.

The personal and social benefits of music are presented by Pauline Black, based on research into jazz improvisation in Scotland. Marc Sarazin discusses the notion of cohesion through interdependence, which underpins the purpose of a collective music programme in French primary schools. His findings suggest that the experience of collective music-making for young people can be mixed.

Community music-making is the focus for two articles. The first of these, by Debra Rodgers, discusses the role that community music can play in countering the stigma associated with mental health issues. Secondly, Andrea Gande and Silke Kruse-Weber present the Meet4Music initiative in Austria, the aim of which is to bring diverse groups, including migrants, together, leading to a suggestion for a conceptual framework for lifelong learning.

Two articles look at music in the context of ICT. Adam Hart discusses the development of composition software for primary school learners, while Carol Johnson considers the shift to teaching music online in higher education. Online technology is also one of the themes in the article by Helen Julia Minors and colleagues, which explores diverse creativities through consideration of five case studies conducted in different higher education establishments.

\footnotetext{
* Corresponding author - email: h.mcqueen@ucl.ac.uk

(C) Copyright 2017 McQueen and Varvarigou. This is an Open Access article distributed under the terms of the Creative Commons Attribution Licence, which permits unrestricted use, distribution, and reproduction in any medium, provided the original author and source are credited.
} 
The final article is about choral conducting. Naomi Cooper proposes a model of informal learning for those becoming choral conductors.

In spite of the diverse contexts, the common thread running through the contributions is a practical and academic interest in the value of learning music. We hope that you will find the content of this feature as interesting and thought-provoking as we did.

\section{Notes on the editors}

Hilary McQueen is Lecturer in Education at UCL Institute of Education She also tutors two psychology-related courses for the Open University, and is a private music teacher and accompanist. Her research interests include effective learners, music education and pedagogy in further education. In addition to research papers, she is author of Roles, Right and Responsibilities in UK Education (Palgrave, 20I4).

Maria Varvarigou is Senior Lecturer in Music at Canterbury Christ Church University. She completed her PhD in 2009 as a scholar of the A.S. Onassis Foundation. Her special areas of interest include music and wellbeing; ear-playing and performance practices of vernacular music; effective teaching and learning in higher and professional education; intergenerational musicmaking; and choral conducting education.

\section{The articles included in the 'Music education in context' feature are:}

Black, P. (2017) 'On being and becoming a jazz musician: Perceptions of young Scottish musicians'. London Review of Education, I5 (3), 339-57.

Cooper, N. (2017) 'Design-based research as an informal learning model for choral conductors'. London Review of Education, 15 (3), 358-7I.

Gande, A. and Kruse-Weber, S. (2017) 'Addressing new challenges for a community music project in the context of higher music education: A conceptual framework'. London Review of Education, I5 (3), 372-87.

Hallam, S. (2017) 'The impact of making music on aural perception and language skills: A research synthesis'. London Review of Education, 15 (3), 388-406.

Hart, A. (2017) 'Towards an effective freeware resource for music composition in the primary classroom'. London Review of Education, 15 (3), 407-24.

Holmes, S. and Hallam, S. (2017) 'The impact of participation in music on learning mathematics'. London Review of Education, 15 (3), 425-38.

Johnson, C. (2017) 'Teaching music online: Changing pedagogical approach when moving to the online environment'. London Review of Education, I5 (3), 439-56.

Minors, H.J., Burnard, P., Wiffen, C., Shihabi, Z. and van der Walt, J.S. (2017) 'Mapping trends and framing issues in higher music education: Changing minds/changing practices'. London Review of Education, 15 (3), 457-73.

Rodgers, D. (2017) 'Community music as a vehicle for tackling mental health-related stigma'. London Review of Education, 15 (3), 474-87.

Sarazin, M. (2017) 'Can student interdependence be experienced negatively in collective music education programmes? A contextual approach'. London Review of Education, I5 (3), 488-504. 